
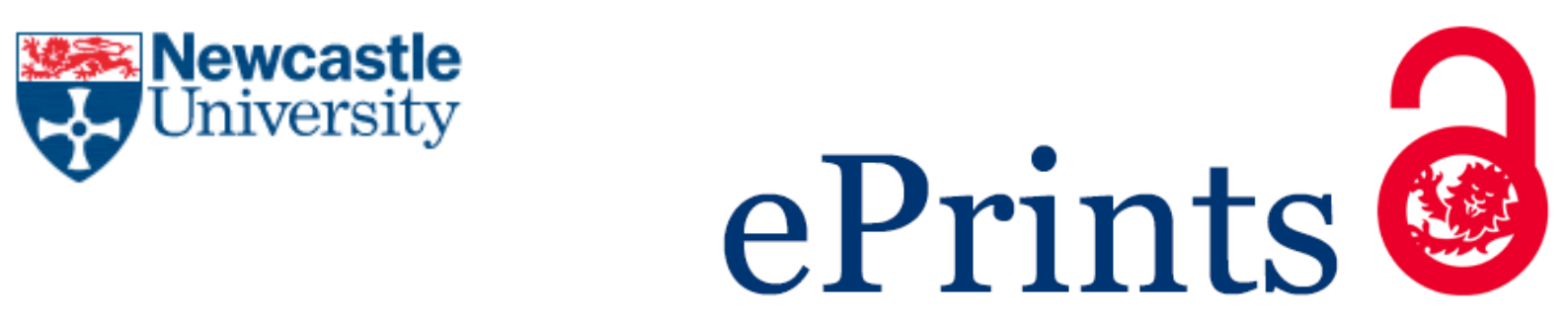

Davies M, Chisholm A.

Neoliberalism, Violence, and the Body: Dollhouse and the Critique of the

Neoliberal Subject.

International Political Sociology 2018

DOI: https://doi.org/10.1093/ips/oly001

\title{
Copyright:
}

This is a pre-copyedited, author-produced version of an article accepted for publication in International Political Sociology following peer review. The version of record is available online at:

https://doi.org/10.1093/ips/oly001

Date deposited:

$12 / 01 / 2018$

Embargo release date:

16 May 2020

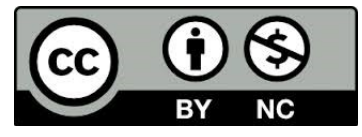

This work is licensed under a Creative Commons Attribution-NonCommercial 3.0 Unported License 


\title{
NEOLIBERALISM, VIOLENCE, AND THE BODY: DOLLHOUSE AND THE CRITIQUE OF THE NEOLIBERAL SUBJECT
}

Forthcoming in International Political Sociology

Matt Davies - Newcastle University and PUC-Rio

Amanda Chisholm - Newcastle University

\begin{abstract}
What is the relationship between neoliberal subjectivities and sexual violence? Prevailing accounts of neoliberalism assert a particular notion of subjectivity, reflected in the notion of homo oeconomicus as an entrepreneur of the self, embedded in social relations of competition, with characteristics to enable behaviours that affirm or reproduce neoliberal rationality. This article, drawing upon the television series Dollhouse, argues for a contrary understanding of subjectivity as concretely embodied, emerging from lived experience shaped by violence. We examine theoretical critiques of neoliberalism, which have not sufficiently explored the integral role of violence in neoliberalism's subject forming process. Dollhouse, read as a theoretically informed diagnosis of neoliberal subjectivity, shows how subjects are produced in embodied, everyday lived experience and how violence - in particular sexual and racial violence - is integral to the inscription of neoliberal subjectivity. This analytical move enables a critique of the neoliberal subject in terms of the lived experience of subjectification, contributing to a political understanding of subjectivity that critiques the depoliticized image of the neoliberal subject.
\end{abstract}


Keywords: Neoliberalism, Subjectivity, Embodiment, Popular Culture,

Gender, Violence

\section{NEOLIBERALISM, VIOLENCE, AND THE BODY: DOLLHOUSE AND THE CRITIQUE OF THE NEOLIBERAL SUBJECT}

The hegemony of neoliberalism has been notably persistent. In part, neoliberalism appears to have survived because it has been so successful at ideologically discrediting and politically dismantling alternatives to its policy prescriptions (Peck 2013, 147). Critics have also noted how neoliberalism accommodates itself to violent, authoritarian states (Klein 2007; Dean 2012; Bruff 2014). When addressing neoliberalism in international contexts, conventional International Relations scholarship has engaged with concepts, such as "resilience" or "vulnerability,"that assume a particular form of subjectivity. Thus a particular kind of subject can be deemed "vulnerable" and therefore "protecting" that subject becomes imperative, or a particular kind of subject can be made "resilient" through proper policies; what a subject is or how it comes to be is taken for granted, not examined. Where conventional IR assumes an already existing subjectivity in their analysis of neoliberal governance, critical approaches to IR have set out specifically to understand the theory of the subject that underlies such key concepts. Judith Butler's explorations of the ethics and politics of precarity, for example, explicitly engage the theory of the subject (Butler 2006; Butler 2009). Additionally, Chandler and Reid (2016) map the neoliberal assumptions about the subject that inform the 
concepts of resilience, adaptability, and vulnerability. The contributions in Gill and Scharff (2011) examine gendered subjectivities in neoliberal and postfeminist times as lived and experienced, as well as represented.

Critical approaches drawing on Foucault account for the persistence of neoliberalism as an ideology related to its theory of the subject as homo oeconomicus (Foucault 2004). Homo oeconomicus presents a disembodied, abstract, and universalising understanding of subjectivity. Foucault's analysis has been instrumental to critiques that explore the political consequences of the disciplinary and governing techniques of neoliberalism (Brown, 2003 and 2015; Crouch 2011; Dean 2012; Mirowski 2015). Feminist scholarship has picked up on Foucault's critique of neoliberalism to explore how neoliberal gendered subjectivities render women more vulnerable to violent economic and social policies in times of crisis (Bordo 1993; True 2012; Hozic and True 2016). The various contributors to Gill and Scharff (2011) explore the ways in which systemic or structural violence shape gendered embodiments, which are obscured or silenced in the postfeminist cultural world.

We argue that neoliberalism's reliance on violence goes deeper: that violence - of various kinds - is necessary to police the neoliberal subject. In this article we explore how the television series Dollhouse examines everyday forms of sexual and racial violence as a condition for neoliberal subjectivity. Our paper shows how neoliberalism, as a strategy for governance, must overcome the practical emergence of subjectivity through lived, embodied experience. The tension then between a Foucaultian understanding of the body as discursively produced and the subject as a lived body, produced through its fleshy 
interactions and entanglements with the world, provides keen diagnoses of violence and subjectification in neoliberalism.

Both Foucaultian and phenomenological approaches challenge us to rethink the relationship between bodies and subjectivity (Ahmed 2001; Beasley and Bacchi 2000). With Crossley (1996), we believe poststructural and corporeal accounts of the body complement rather than discount each other. For both, "the body is not simply an outcome, it is not simply written upon, but materializes the operations of power in social life" (Balsamo 1996: 3). Dollhouse explores the conflicts and synergies between the two accounts of the body, advancing our analysis of the governed neoliberal subject and the emergence of other subjectivities.

After a description of Dollhouse, our argument turns to a short survey of theoretical accounts of the neoliberal subject. We then examine how Dollhouse develops a critique of subjectivity situated in neoliberal relations of production and reproduction, accounting particularly for the sexual violence sustaining these relations but further noting how racial violence contributes to violent sexual subjectification. We conclude with some reflections on the subject as body, a political and aesthetic subject (Shapiro 2010,179-180) that belies neoliberalism's abstract and homogeneous presuppositions about subjectivity.

\section{Why Dollhouse?}

Dollhouse was Joss Whedon's fourth television series, after Buffy the Vampire Slayer, Angel, and Firefly. Whedon's programmes often had fraught relations with the networks that broadcast them: Buffy switched networks, though it concluded its original story arc across seven seasons; Angel came to an 
abrupt end after five seasons; Fox cancelled Firefly after a single season. Dollhouse always suffered a tenuous place on the broadcast schedule. The programme came out in 26 episodes over two seasons in 2009-2010. Fox broadcast it on Friday nights, a dead zone in the schedule when viewer numbers are typically low.

Thus Dollhouse was not "popular" in the sense of enjoying a large audience; however, the show examines many tropes embedded in popular imaginations, such as women's sexual availability and its regulation; women as damsels to be rescued or ingénues to be molded; women as exotic - that is, marked as different and foreign in the intersections of race, colonialism, and class; or women as "equal" to men in "lean-in", "postfeminist" corporate cultures. By exploring and problematizing these tropes, Dollhouse as an artifact of popular culture intervenes in debates on neoliberalism as it articulates its own and its viewers' positions in cultural production (Benjamin 1978; Davies 2005; McRobbie 2009; Dunn 2014).

At the same time, such artifacts have distinctive features and must be analyzed on their own terms. Rather than being driven by analysis of data, for example, Dollhouse critiques through narrative and character development. Furthermore, it engages with lived experience by situating narration and characterization in the conflicting temporalities that cleave the everyday: the drive to resolve narrative crises clashes with the rhythmic return to beginnings just as ends and cycles order the everyday. Dollhouse expounds its points about the politics of neoliberalism through the ways that bodies produce, are brought into relation, and are marked in space. 
The Dollhouse is a business that supplies human "Dolls" who have been programmed to fulfil the fantasies of wealthy clients. Dolls often engage in sex and fantasy work and clients are typically white and male. Dolls work under fiveyear contracts with the Dollhouse. The contract stipulates that their bodies will be used for the Dollhouse's purposes but that at the end of the contract they will have their bodies returned, with ample financial compensation. The "volunteers" who sign the contracts are sometimes under duress, often in emotional turmoil, with absent families or social networks when they sign the contract. So while contracts have been signed, it is made implicit that recruitment of Dolls is rendered possible through social, political, and economic inequalities that render certain populations more amenable to coercive contractual agreements in the first place (Chisholm 2014).

The Dollhouse uses technology that can upload and store a person's memories and personality while installing neurobiological "architecture" that makes the person programmable with other memories, capacities, and characteristics to satisfy clients' particular needs. Thus a Doll is "wiped" and then "imprinted" with new features on demand. This process takes place in a corporate-clinical environment. An operator administers the "treatments" via a computer, with Dolls seated in a reclining chair with electrodes positioned on their temples. The Dolls' "Handlers" are present, observing the procedure. The visual expressions on the Dolls, the stiffening of their shoulders and arching of their backs and the moaning they vocalise during the treatment indicate that the process is physically painful.

When in the Dollhouse, the Dolls are seen as having very limited abilities, child-like in their demeanours and speech. Dolls are passive, speaking in soft 
tones with vacant expressions on their faces. The other workers in the Dollhouse - from Topher Brink, to Dollhouse security chief Laurence Dominic - refer to the Dolls in demeaning and insulting terms - as pets for example. When in the field on "engagements", the Dolls are referred to as "Actives", reinforcing the assumption of a dichotomy between their programmed "active" state and their passivity as Dolls.

The Dollhouse also refers to the place where the Dolls are maintained. It is a self-contained and self-supplying spa located 10 stories underground, beneath a building in Los Angeles. The spa is vaguely Asian in design: Dolls are massaged, practice Tai Chi, yoga and bonsai, and eat organic fresh foods. The lab where new personalities are imprinted or wiped is located there.

Besides Ballard (the FBI agent), Topher (the scientist), and Adelle DeWitt (LA Dollhouse chief executive), other core protagonists for the programme include Boyd Langton, initially a Handler charged with protecting the Actives when in the field. The imprinting process psychologically binds Dolls to their Handlers. As Dolls comes back to consciousness, they recite a dialogue with their Handler that includes a declaration that "I trust you with my life".

All of the Dolls are given names that refer to the NATO phonetic alphabet. Eliza Dushku (also the producer of the series) plays Caroline Farrell, a student activist who has set out to expose and take down the Rossum Corporation only to find herself, in the opening episode, in an office where DeWitt is making her an offer she cannot refuse: to sign away five years of her life to be a Doll, in exchange for making her problems (presumably legal but perhaps also financial problems) go away. Caroline becomes Echo. Sierra and Victor are Dolls who sleep in the same pod as Echo; their attraction to each other is one of the early 
signals of the limits of the technology for "wiping" a subject. Whiskey is a Doll who has been imprinted with the characteristics of a medical doctor, to replace one who was murdered in the Dollhouse. November is "sleeper" Doll who has been put into Ballard's life in order to neutralize his investigations. Alpha, the "big bad" in season 1, is a Doll who has had a process go wrong as his various personalities have been imprinted simultaneously, making him a multiple personality psychopath with the skills and intelligence of all his imprints.

The Dollhouse is part of a larger enterprise, Rossum Corporation, which, at least publicly, is in the business of medical research. While the Dollhouse is secret and illicit, it is supplied with a moral rationale: to raise money to support Rossum's medical research ("Echoes", s. 1, ep. 7). At the same time, the manifest purposes of Rossum are not the secret or esoteric purposes: Paul Ballard, the FBI agent who is attempting to investigate the Dollhouse, is told at various points that the business of the Dollhouse is fantasy but that is not its purpose.

\section{Dollhouse and Neoliberal Subjectivity}

Studies of popular culture, such as those of Thorsten (2012), Shepherd (2013), or Griffin (2015), show how artifacts of popular culture produce and circulate cultural meanings and practices that complicate prescriptive rationalities, like the neoliberal notion of subjectivity, because they generate occasions for counter-readings shaped by the complexities of subjective experience. Thus "popular renderings of the limits of acceptable subjectivity" (Beier and Mutimer 2014, 323) are themselves an important form of political critique. Dollhouse diagnoses the structure of neoliberal subjectivity and how its compulsions and limitations play themselves out. As a feminist reading of 
neoliberal subjectivity, Dollhouse also highlights the contradictions of the gendered neoliberal subject, the disembodied notion of subjectivity that this subject rests on, and how the sexual and racial violence that often enables it, materially underpins the constitution of neoliberal subjectivities.

Dollhouse's political critique of neoliberalism starts not by locating the structural and historical forces that generated neoliberalism but by accounting for the subject as body in its concrete and variegated spaces. To do so, Dollhouse situates the subject in particular relations of production and reproduction that are enforced through sexual and racial violence. For neoliberalism, subjectivity is a set of qualities for an ideal-typical homo oeconomicus (Foucault 2004) in a properly ordered world. Dollhouse, in contrast, demonstrates a contrary understanding of subjectivity as embodied, as a concrete essence emerging from lived experience. Dollhouse's situating of subjectivity in social and technical divisions of labour and in the role of sexual violence in producing and maintaining them not only identifies the conditions for neoliberal subjectivity but also the limits and openings afforded by these conditions.

\section{Neoliberalism, Subjectivity, and Bodies}

Neoliberalism is prescriptive inasmuch as it asserts how humans are and must be in order to be free subjects, while as a strategy of governance it flexibly adapts to diverse circumstances to realise and police the conditions upon which its notion of subjectivity is premised. In short, neoliberalism is based on an assertion about how the world is but in practice, it has to bring that world into being (Lemke 2002; cited in Read 2009, 30). Its universalised claims about what 
a subject is must be "brought inside" subjects in particular circumstances (Peck 2013, 143; Gill 2008, 433; Gill and Scharff 2011).

Neoliberalism's strategies for bringing about its universal vision must thus be "hybridized" with specific modes of governance in particular circumstances (Peck 2013, 140). It reconfigures relationships between the governing and governed, power and knowledge, and sovereignty and territoriality (Ong 2006). Neoliberalism has proven to be quite flexible circumstantially. Departing from an idealised commitment to rolling back the state, for example, neoliberalism has accommodated itself to expanded, authoritarian states in order to police both the implementation of its policies and the conditions governing the extension of market rationalities into noneconomic areas of social life (Bruff 2014). Its reliance on the violence of the authoritarian state (Klein 2007, Dean 2012, Bruff 2014), though at odds with its account of a pristine homo oeconomicus, is unsurprising.

Neoliberalism depends on a notion of the subject not as a given in a social field that aggregates individual subjects - which is liberalism's typical understanding of the subject - but as something that must be made to conform to the requirements of a competitive social order: society modeled on the competitive pressures of the market. The individual subject is no longer a mere trader, with an innate propensity to truck and barter, but must become an entrepreneur of the self, “...being for himself his own capital, being for himself his own producer, being for himself the source of [his] earnings."'” (Foucault 2004, 226; see also Mirowski 2014; Brown 2015). The neoliberal subject invests in its "human capital" (Becker 1993) to be able to adapt to changes wrought through competing. Neoliberalism is particular, meaning different things to 
different people depending on one's vantage point (Ong 2006, 6). That said, neoliberalism is simultaneously global, through its violent policy reform or through development initiatives (Gill and Scharff 2011, 6; Peck 2013; Chandler and Reid 2016).

Through foregrounding competition over exchange, neoliberalism extends the domain of economic rationality beyond narrowly economic concerns: "Rational conduct is any conduct which is sensitive to modifications in the variables of the environment and which responds to this in a non-random way, in a systematic way, and economics can therefore be defined as the science of the systematic nature of responses to environmental variables" (Foucault $2004,269)$. For the neoliberal subject, the social itself is a realm of competition: the social ties subjects have to each other individualize the subject by winnowing out weaknesses and rewarding success through competition. The neoliberal subject crafts itself to and for others ("invests in human capital") on the basis of dynamic and creative adaptations of capacities encountered through the field of the social as market. For neoliberalism, self-discovery and self-making are confined to and subsumed under market rationalities (Brown 2015; Rose 1989). For neoliberalism, the subject is only autonomous, its ends are only ever self-determined, in the most general sense because particularly, the subject must adapt to the shifting demands of competitive markets-in fact, the neoliberal market rationale demands this of the subject. Competition produces winners and losers, thus the concrete qualities of the subject must be flexible and fungible. Vulnerability, for neoliberalism, is seen in terms of risk. It is something that must be identified and contained. Privilege is a marker for merit in a competitive hierarchy (Davies 2014). Winners and losers are subject to a "savage sorting" 
(Sassen 2010). Losers, having presumably assumed the risk of entering the social field mediated by competition, are responsible for their own outcomes and can be ignored or discarded (Crouch 2011, 42). Dollhouse's season finales, "Epitaph I" (s.1, ep. 13) and "Epitaph II" (s.2, ep.13) project this logic of feral competition between atomised people to a nightmarish vision of social breakdown.

Neoliberal subjectivity is thus abstract - that is, defined outside of and prior to concrete lived experience - and homogeneous - that is, indifferent to differences generated in the social field, such as gender or race. Neoliberal subjectivity appears as a singular goal that succeeds or fails in terms of the subject's capacity to be resilient and flexible. Neoliberalism reduces the body to an object - a blank slate to be wiped and inscribed upon. The neoliberal representation of subjectivity as disembodied, abstract, and homogeneous denies and ignores the practical, social, and cultural lives of subjects; the implementation of neoliberal subjectivity requires a policing - sometimes violent policing - of lived experience.

Thus for neoliberalism, the theory of the subject as homo oeconomicus rests on axiomatic assertions that appear as the premises on which its theories of the fulsome operations of market economies rest. The subject for neoliberals is an atomised individual who is compelled to be free to act rationally in pursuit of non-prescribed self-interests. The market is the accumulation and operation of knowledge, communicated to individuals as price signals. The genius of Foucault's engagement with neoliberalism is that he demonstrates how the market as knowledge (i.e., prices) disciplines the body, how the market is every bit as much a panopticon as the prison or the clinic is, and thus how the individual becomes a subject by internalizing the rationality of economic utility. 
Williams summarizes Foucault's approach: "Power individualizes, classifies, manipulates the body according to certain precepts of knowledge. It develops skills and strengths where weakness and instability previously lay. In modern society, the subject, following the law of economic utility, must be a cost-effective unit" (Williams 2001: 179). For neoliberals, the individual is the bearer of subjectivity, subjectivity belongs to the individual; for Foucault, the individual subject is an effect of power; subjectivity is inscribed on an individuated body.

For both, however, subjectivity is an ideal form, an abstraction to which individuals (more or less successfully) conform. Neoliberals are able to dispense with non-conforming subjects by making them - theoretically, violently, and through policy - responsible for their failure to conform: if you fail as a subject in neoliberalism, it is your responsibility; you must accept the consequences of your failure. Foucault's conception of the market as panopticon argues that individuals will tend to self-discipline, while examining the non-discursive, the material and institutional bases for the production of this self-discipline. Foucault's critique shows how the neoliberal intention to assume away power nonetheless depends on power relations to produce subjectivity but in doing so, he shares with neoliberalism an axiomatic approach to subjectivity: for both, subjectivity is defined prior to the actions of concrete subjects. There is no conceptual scope to imagine subjectivity being anything other than neoliberal (Gill 2008, 434).

Bodies, Vulnerability, and Violence

How do we begin to think about subjectivity as otherwise to this neoliberal story? One way of approaching subjectivity not as an abstraction 
would be to see it as a capacity of the body: not the body as inscribed with subjectivity but the body as a subject. As we will see, Dollhouse posits this possibility politically, as a disruption of the disciplinary and biopolitical neoliberal subject. Feminist IR scholarship has critiqued embodied female subjectivity in the context of neoliberalism in various ways, focusing on the ways in which gender is a disciplinary tool that increases surveillance or increases risk and insecurity (Gill 2008; Elias 2013; Fraser 2013; Rottenberg 2014; Prügl 2015; Hozic and True, 2016; Repo 2016; Tepe-Belfrage and Montgomerie 2016).

Other IR scholars critical of neoliberalism have engaged somewhat less with literature examining how sexual violence produces gendered bodies and acts to discipline gender hierarchies. Exceptions include Agathangelou's (2004), True's (2012) and Meger's (2015) political economic analyses of gender-based violence. Each shows how violence is materially embodied and rooted in broader global gender and racial inequalities. Feminist work in popular culture has also addressed this concern. Shepherd's analysis of the television series $\mathrm{Oz}$ examines rape as a violent means of producing and distributing sexuality (Shepherd 2013). Griffin's research on women in popular culture demonstrates how the "women in refrigerators" trope explicitly enables male agency through the murder of female protagonists (Griffin 2015, 125-129).

Dollhouse examines how subjectivity emerges through "intercorporeality": that is, how subjectivity develops in bodies in relation to each other, through their entwining with, participation in, and appropriation of the world (Merleau-Ponty 2001; Coole 2007, 161; Dejours and Deranty 2010). The body is an open, metabolic system, absorbing, transforming, and exchanging materials and energies with its environment (Lefebvre 1991, 176). Thus bodies 
exist in relations to each other and in space, not as atoms (Coward 2012: 469): a body is always already intercorporeal. Intercorporeality obviates Cartesian mind/body dualisms because the subject is a body situated in a phenomenal world and intertwined with that world and with other subjects (Leys 2011; Vij 2013).

Merleau-Ponty develops his conception of intercorporeality through considering the reflexivity of relations between bodies (Merleau-Ponty 2001, 185; Morris 2012, 116). Morris explores his conceptualisation of the body as a subject in part through the implausibility of understanding the body objectively, as an object (Morris 2012: 112-119). In lived experience, our ability to interpret the physical expressions of other bodies, such as anger, aggression, or shame, could be described as a process of reading physical signals, analytically comparing them to other signals and expressions that we can recall, detailing similarities and differences in order to correctly interpret the signals, and thus sorting and naming the signals according to verified theories of other minds. However, for most people, this does not plausibly describe what they actually do when faced with an angry, aggressive, or frightened person: our bodies already understand or misunderstand these signals without having to go through an analytical process and calculation in the mind; the red face or the clenched fist is not an expression of some representation of anger, they are the anger.

Merleau-Ponty's famous example of touching his left hand with his right, an encounter in which touching and being touched are distinguishable and simultaneous, thus intertwined, is repeatable with another body: bodies are intertwined palpably - tangibly through touch, for example, or visibly through sight. Because of this intertwining, the "interior" experience of the individual 
subject cannot be privileged. Intercorporeal being is "a presumptive domain of the visible and the tangible, which extends further than the things I touch and see at present" (Merleau-Ponty 1968: 143).

Such intertwining of bodies is not unstructured. Being intercorporeal can mean being dependent or vulnerable. The reciprocity and reflexivity underpinning intercorporealty mean that the body-subject must be open to other bodies in the phenomenal world. Many feminists have criticised MerleauPonty's conception in part because this prereflective reciprocity seems to imply non-hierarchical equality between bodies and that those bodies are normatively masculine in their intentionality towards the world (e.g., Young 2005). But there is nothing in Merleu-Ponty's account of intercorporeality that precludes difference - indeed, different bodies are assumed to be the reciprocal sides of the phenomenon - and nothing precludes hierarchical relations between bodies nor different techniques and tactics in reciprocal interactions.

Judith Butler (e.g., 2006; 2009) has brought corporeal vulnerability to the foreground in political and ethical debates. Chandler's and Reid's Foucaultian analyses also map out the ways that neoliberalism inscribes subjectivity as vulnerability and how casting subjects as vulnerable enables both violent and policy interventions to secure the subject (Chandler and Reid 2016). Their approach, like that of the Foucault-inspired analyses of the neoliberal subject examined above, helps draw attention to the ways bodies are marked - by racialised and colonial violence, by gender and sexual violence - and distributed hierarchically.

However, vulnerability and dispossession are lived out in radically different (Murphy 2011: 589) and ambiguous (Murphy 2012) ways. To see 
vulnerability only from the perspective of how it is imprinted on the body, rather than a body's capacity to relate to other bodies, reduces the body to an object subjectivity becomes a matter of privilege as the subject-object relation is preserved. Dollhouse acknowledges various instances where a dominant figure abuses a privileged agency to use vulnerable bodies - much of the narrative across all twenty six episodes is premised on such usages - but it simultaneously explores the subjectivity of the Dolls, how subjectivity emerges from their embodied encounters with an intercorporeal world.

Vaittinen (2015) explores how the vulnerable body produces a constant opening of the political. Vulnerability does not necessarily mean market-oriented risk as neoliberal logics assert. Nor does it result in an immediate violence upon the body. Vulnerability is more ambiguous (Murphy, 2012). It can be lived as a constant opening, a blurring and negation of the fully bounded self. In this case, vulnerability can also lead to empathy, a realised deep connection with other bodies and environments (Bulter 2006; Käll 2016). For Vaittinen, Bulter, and for Käll, vulnerability is not a condition to be remedied by making a subject resilient; it is a recognition of the interdependence of the living body on the world and on others. These arguments focus on how the labour of caring for the vulnerable describes a political field in which the relations between the vulnerable and their carers are driven by the inevitable neediness of the body and the responses to that need.

At the same time, violence is also specifically intercorporeal (Shepherd 2008; True 2012; Wilcox 2014). Violence marks us and our bodies bear the memories of trauma. Scarry (1985) shows how violence, articulated through pain, un-makes the world. Pain reduces the intercorporeal body to an 
individualised atom, retreating into and referring to itself, isolating the body from the social. This is also how the productive body operates in neoliberal terms: flexibility with regard to externally imposed tasks requires the bodysubject to be objectified, atomized, and instrumentalised - including biological flexibility "at the glandular level", as Topher Brink - the computer scientist who designs and runs the machinery for wiping and imprinting the Dolls - puts it ("Instincts", s. 2 ep. 2).

"You ever try and clean an actual slate?" Neoliberal Marks on the Body

A core question that motivates character development in Dollhouse has to do with what a person - as a "self" - is, and how a person acquires her or his abilities, memories, and character traits. The presumption behind the technology and the everyday management regimes of the Dolls is that these capacities are at once abstract - a "mind" that can be removed, programmed, and replaced in different bodies - and flexible, that is, the characteristics of a person can be shaped according to the needs of a client or of a situation. These are the fundamental qualities of the neoliberal subject and Dolls demonstrate their aspiration to be this kind of subject through the phrases they repeat throughout the series: "I try to be my best" and "was I my best?". But as the narrative and the characters of Dollhouse develop, the limits to that technology and the ways in which it fails come to appear as a function of the limits of this theory of the subject. Subjectivity is not and cannot be disembodied, as the industrialised "wiping" and "imprinting" processes assume. Caroline notes this at the outset when she asks DeWitt if she has ever tried to wipe an actual slate clean. 
The limits to "wiping" subjectivity from the body make themselves felt as a "glitch": Victor and Sierra fall in love in their Doll states: even supposedly "wiped" of their subjective capacities, their bodies tacitly recognize and are drawn to each other Like vulnerability, love plays a foundational role in subject formation. Love as a "properly political transformative concept" (Berlant 2011, cited in Choi 2015, 127) rests on worldly intercorporeality. For D’Aoust, to examine love "enables us to simultaneously capture the intstrumentalization and unexpected openness of agency which intensities recognized as 'love' might enable" (D'Aoust 2013, 261). Sierra and Victor are repeatedly drawn to each other, even after their "treatments," because their bodies remember each other.

The body remembers: this is also the quality of Echo's body that Rossum sets out to appropriate. Rossum's medical research includes the cultivation of Echo's spinal fluid to immunize select clients from the effects of their technology: Langton reveals that Echo's residual subjectivity in the Doll state is the physical quality he was attempting to develop as her Handler. However, Rossum is vulnerable precisely to Echo's emergent subjectivity, as she resumes Caroline's efforts to take the corporation down. In Dollhouse the efforts of the dominant subjects to distribute vulnerability in order to make themselves invulnerable consistently fail, not only as a function of the narrative but also because such efforts fail to understand the subject as a vulnerable body.

Neoliberal Hierarchies and Gendered Divisions of Labour Dollhouse shows how the relationship between violence and neoliberal subjectivity rests on three practices. First, gendered social and technical divisions of labour sustain the corporation in a neoliberal context. The 
corporation as a biopolitical institution depends on a gendered division of labour and violence polices the insertion of subjects into that gendered order. Second, the abstract and disembodied picture of the neoliberal subject, such as homo oeconomicus, must be inscribed on bodies made objects. While the objectification of the body often takes place through habitual practices (Young 2005), violence and the threat of violence also police the proper behaviour of the subject. Discourses around "how not to get raped" exemplify this implicit violence. Finally, Dollhouse demonstrates that not only does the objectification of the body depend on violence, so also does its subjectification.

Dollhouse highlights the gendering of subjectivity in various ways: strikingly, the gendering of the subject takes place through the ways that labour is divided and social relations are reproduced. Most (though not all) of the Dolls are women; most (though not all) of the Handlers are men. Dolls - including the male Dolls - are rendered passive, first by turning their bodies over to be used for both the "business" and the "purpose" of the Dollhouse and then through the subjectively depleted condition of the Dolls who turn their lives over to their Handlers. The process of imprinting the Dolls is penetrative and painful: needles and electrodes going into their bodies to download or upload experiences, memories, and skills to the installed architecture that makes them receptive to the imprinting process.

Handlers, on the other hand, are physically active and explicitly in charge of and responsible for the welfare of their charges. Laurence Dominic, who begins the series at the chief of security for the LA Dollhouse, is impassive, compassionless, and ruthless. Ballard, at first an FBI agent attempting to expose and undermine the Dollhouse but later co-opted and made Echo's Handler, 
releases his frustrations through practicing kickboxing. Langton, initially Echo's Handler, takes a very paternal stance towards her and he is cultivating - or sees himself as cultivating - Echo's special subjective capacities. Langton even explicitly situates himself as pater familias once his identity as one of Rossum's founders has been exposed in the episode, "The Hollow Men" (s.2, ep.12): he has chosen group of people around Echo (apart from Ballard) because he sees them as his family.

If the abstract and homogenous form of subjectivity posited in neoliberalism denies or ignores gender differences, the more robust embodied understanding of subjectivity in Dollhouse shows how such differences are essential to the corporate order. The ways that men can be Dolls or women can be authorities of various sorts only slightly complicates the gender order of neoliberal subjectivity in Dollhouse. For example, Adelle DeWitt, the LA Dollhouse's CEO, initially appears as an expression of postfeminism or neoliberal feminism (Elias 2013; Rottenberg 2014; Roberts, 2015). She must be ruthlessly self-interested and committed to self-preservation but these qualities are tied strongly to the corporate interests of Rossum. She must compete with another Rossum executive, Matthew Harding, for control over the LA Dollhouse. Neoliberal sexual "equality" makes DeWitt equally a CEO, equally aggressive and competitive, equally ruthless in pursuit of corporate ends ("purpose"). However, in a crisis moment of the narrative arc, DeWitt chooses to nurture Topher, politically committing herself to the struggle against Rossum through the labour of care she gives to Topher (Vaittinen 2015), while Dominic chooses to fight, and Langton chooses to bring the "family" together to eliminate threats to it. 
Non-market but nonetheless "authorised" uses of the Dolls illustrate this gendered difference in positions of authority. In "Haunted" (s. 1, ep. 2), Topher imprints Sierra as his gamer buddy to celebrate his birthday. It is an adolescent, though non-sexualised, fantasy but Topher's use of Sierra is tolerated because he is a valued worker. However, DeWitt is shown to be using Victor in "A Spy in the House of Love" (s. 1, ep. 9) for illicit encounters and in "Belonging” (s.2, ep.4), Harding subtly compels her to sacrifice Sierra by noting that "everyone" might take their work home with them, referring to her indiscretions. The point is that for Harding or for Topher, using the Dolls for personal purposes can be a perquisite of the job but for DeWitt to do so creates an opportunity for Harding to threaten her - because she is a woman. Neoliberal subjectivity elides gender so DeWitt can be an authority but it reproduces a gendered hierarchy in order to police the social order.

Thus the social labour of the Dollhouse is divided and a gendered hierarchy of social relations ensues. Langton and Clyde Randolph, the founders of Rossum Corporation, establish the corporation to create technology that produces a disembodied and transportable subjectivity through wiping and imprinting tacit knowledge and personality traits, which enables a commodified form of neoliberal subjectivity. The gendered hierarchy of the social world, in which Dolls as much as Handlers and corporate executives must live, enables Rossum's technology to make possible a flexible self that can be adapted to the requirements of any particular demand asserted in any market for an employee. The "savage sorting" (Sassen 2010) performed in the Dollhouse distributes the privileges of the qualities associated with the neoliberal subject to the active masculinised characters, the work of sustaining those privileges to the 
commodified bodies of the feminised Dolls, and it discards failed subject/bodies into the chaos of the imprinting technology run amok or into the "Attic" for punishment.

Langton and Randolph, and most specifically Clyde 2.0, are "entrepreneurs of the self" in relation to this technology. Langton, through his interventions in Echo's development, assumes different roles, flexibly and tactically nurturing Echo's emergent bodily subjectivity. Clyde 2.0 is fully a neoliberal subject, disembodied and free-floating, using and abandoning bodiesas-raw material (including abandoning his original body) as a fully free self, asserting his own vastly expanded free choice without responsibility for his actions of or outcomes for others.

Topher and Bennett Halverson - Topher's counterpart in the Washington DC Dollhouse - are similarly positioned as neoliberal subjects. Given the freedom to play, instead of work, they recall creative workers in the "campuses" of computer software and hardware engineering firms, made "free" to play in order to maximise their productivity. Along with Langton and Randolph, they enjoy a position of freedom to operate according to their own designs and desires with very little accountability. These free-floating subjects are not obviously gendered, at least not initially, but their freedom and flexibility relies on a corporate body that is strictly ordered by gender relations.

The Violence of Objectification and Subjectification

Reading Dollhouse as a commentary on neoliberalism shows the conflicts between the abstract neoliberal subject - the subjectivity that is adequate to living in a neoliberal world - and concrete subjects living and working in that 
world. An important dimension of these conflicts, as we have discussed, manifests itself in the way the division of labour - through the Dollhouse and in its relation to the Rossum Corporation - produces and relies on gendered roles: a gendered division of labour. But the narrative of Dollhouse goes further than this, towards what Agathangelou describes as the "anatomization of ... violence and terror" $(2013,472)$.

Much of Dollhouse's narrative is driven by the objectification of women, misogyny, and sexual and sexualised violence. Joss Whedon's avowed feminist credentials seem strikingly at odds with the ways that objectification and sexualised violence play titillating roles for the viewer in the series. Such a reading of the programme was encouraged by promotional material produced by the Fox Network for the programme: promotional photos distributed in 2009 included not only some stills from the show but also a number of photos of Eliza Dushku in lingerie or nude (http://www.buddytv.com/slideshows/dollhouseeliza-dushku-nude-promotional-pictures-263.aspx accessed 04 September 2015). Fox thus makes use of Dushku's body - not that of her character in the programme - to produce teasing images of sexual availability to associate with the show. Similarly in on-air spots promoting Dollhouse and The Terminator: the Sarah Connor Chronicles, Summer Glau and Eliza Dushku play up the theme of women available for the viewer's entertainment:

Summer Glau: "Where else are you going to find a couple of girls like us..." Eliza Dushku: “...who can be everything you want: smart, stylish...” Summer Glau: “...and strong enough to throw a car...” Eliza Dushku: “...so let’s make Friday night our little date night...” (https://youtu.be/snLEZoMmop4 accessed 04 September 2015). 
In the narrative arc of Dollhouse, the premise behind the wiping and imprinting technology is precisely that the bodies of the Dolls are made into objects: cognitive functions are reduced to the minimum necessary to take care of the Doll's bodies and any assertion of selfhood or evidence of self-awareness is treated as a "glitch" that must be corrected. Clients' authorised use of Dolls for sexual gratification is established in the first episode, "Ghost" (s. 1 ep. 1), when Echo first appears on a date with a client that involves sex and even the hint of a possible emotional connection - one that will be wiped when Echo returns to the Dollhouse for her treatment. In the following episode, "The Target" (s. 1 ep. 2), Echo once again has been imprinted as a date for a long weekend of camping with a client who, to fulfil his fantasy, turns her loose into the wilderness to hunt and kill her. "Ghost" links sex with violence in Echo's second imprint in the show, when she becomes a psychologist who specialises in negotiating the release of kidnapped children. One of the kidnappers had sexually abused Echo's imprinted personality in her childhood and thus to rescue the kidnapped child, she needed to defeat the molester. She rescues the child by outwitting the kidnappers through exposing and emotionally deranging the molester: she turns her sexual damage against him; she also kills her tormentor in "The Target" by outwitting him. Although in both cases Echo is "the rescuer" in these rescue narratives, it is clear that she is also the damsel being rescued. The sexualised violence - child molestation, sexualised murder for fun - are the conditions surrounding Echo's burgeoning entry into self-awareness and subjectivity and this subjectivity appears in these opening episodes in neoliberal terms: Echo is ultimately responsible for her own condition and must take steps - or, as Foucault says of 
Becker's conception of homo oeconomicus, must "accept reality" (Foucault 2004, 269) - as a subject capable of self-rescue by becoming "the correlate of a governmentality which will act on the environment and systematically modify its variables" (Foucault 2004, 271).

The way that clients are authorised to use Dolls for sexual gratification stains and compromises the less sexualised needs of the clients because in every case, the point is to provide a subject (an Active) whose personhood matches the needs of the client. The episodes "Man on the Street" (s. 1, ep. 6) and "Instinct" (s. 2, ep. 2) make this point explicitly. In "Instinct", Topher brags that he has been able to imprint Echo so deeply that in her role as the mother of a newborn, she has begun to lactate and can breastfeed the baby.

In "Man on the Street", Echo is supposed to meet her client, Joel Mynor, at a modest suburban house - his fantasy is to make a gift of the house to his dead wife, who had been killed in an automobile accident on her way to meet him at that house. Ballard, obsessed with finding the person that Echo used to be, confronts Mynor when the engagement goes awry and Mynor points out to Ballard that his own rescue fantasy is no different to Mynor's fantasy of living the moment of joy he had been denied by the death of his wife. Ballard seeks to convince himself that his feelings are different by returning to his apartment and beginning a sexual relationship with Mellie, a neighbour who has an evident crush on him. Mellie, however, turns out also to be a Doll who has been imprinted and placed in Ballard's life to monitor him and when necessary, interfere with his investigations. The sexual economy surrounding the Dollhouse is organised to systematically ensure that the proper subjectivities emerge. The 
episode ends with Echo arriving to complete her engagement with Mynor: order has been restored.

The level of exploitation of women's bodies is made overt in "Man on the Street". One of the Handlers, Joe Hearn, is revealed to be using his Doll's dependence on him as an opportunity to rape Sierra regularly. The scenes where the rapes take place are harrowing: the Handler uses the language he and the Doll have been provided to police her trust in him ("Do you trust me?" "With my life"), in order to compel her to submit to him sexually, illustrating one side of the politics of the labour of caring (Vaittinen 2015). Despite having her sense of self or subjectivity "wiped" between engagements, Sierra does not passively accept her violation: she is hesitant and pain and fear are clearly evident on her face. These shots are important because they reflect the same pain and fear on the face of the Dolls as they undergo their "treatments", where they are wiped. The look of terror on the supposedly non-subjective and compliant Sierra's face also reflects the terror of the kidnapped women in "Belle Chose" (s.2, ep.3). The penetrative violence of the treatments is clear both concretely, through the use of electrodes and wires in scenes that mimic electroshock therapy, and abstractly, through the notion that the personalities of the Actives can be implanted or removed through this intrusive procedure. That the Dolls must be compelled to become the passive receptacles of whatever personalities or capacities demanded from them is made clear both in DeWitt's recruitment of Caroline in the opening episode and reiterated when DeWitt recruits a new Doll in "Echoes" (s.1, ep.7): both are compelled to choose to enter into a contract with the Dollhouse. 
Sierra's backstory is explicated across two other episodes, "Needs" (s. 1, ep. 8) and "Belonging" (s. 2, ep. 4). Her story shows how violence is not only gendered but also raced. "Sierra" was Priya Tsetsang, an Asian-Australian migrant and artist who sells her artwork near the beach in LA. She becomes an obsession of Nolan Kinnard, a neuroscientist working for Rossum. Because she rejects his advances, he drugs her and sends her to the Dollhouse to be wiped, given the imprinting architecture, and then made available to him as a client. Unlike other Dolls, then, Priya never "voluntarily" agrees to become a Doll and thus her use by Kinnard is without consent - he rapes her, even when her imprints go willingly. This narrative shows us what postcolonial and black feminists have long argued: that violence against women is not only legitimised through patriarchy, but also through legacies and structures colonialism and imperialism (Henderson, 2012; Agathangelou 2004; Davis 1983). Her objectification in the Dollhouse makes Priya into an exotic object for Kinnard's possession. Her tenuous political and economic status within the US makes her vulnerable to violence in ways that other Dolls are not and she is violated in ways other Dolls are not.

When Kinnard is exposed, he demands that she be given to him on a permanent basis; when DeWitt and Topher are compelled to comply, the send her back to him as Priya so she can confront him. This manic, neoliberal rescue fantasy (Mai 2013) securitizes Priya as "high risk", endangering her in the name of empowering her. Echoing the fate of Joe Hearn, Kinnard is killed in the struggle that ensues. De Witt and Topher's plan backfires, leaving Priya extremely shaken and asking to have her memory permanently wiped. 
Thus in the sexual economy of the Dollhouse, when rape is an unauthorised use of women's bodies, the rapists must be killed to ensure that only proper subjects interacting through market-mediated relationships populate the social, economic, and sexual fields and that the threat of policing through sexual violence remains covert. Overtly, the market relations between Dolls and clients are not relations among equals: the flexibility of the clients' needs determine both their own subjectivity and that of the Dolls. Flexibility for the Dolls means the ability to adapt to the demands of the market for their physical and subjective qualities. This unequal structural distribution of subjectivity is produced and enforced through sexual violence, as Echo's and Priya's/Sierra's stories illustrate. Rape is part of the broader field of violence that defines the conditions of possibility for the neoliberal subject.

The "business" of the Dollhouse is to supply flexible, commodified subjects to meet the demand for forms of interaction that allow the clients to develop and sustain their own subjectivity. But the business of the Dollhouse is not the purpose of the Dollhouse, as the programme repeatedly reminds us. In the Dollhouse, the distinctions between authorised sexual violence and that of other penetrative, intrusive, and coercive uses of bodies for the needs of the dominant agents are too fine to draw. Stated differently, the latent purpose of the Dollhouse is to protect and sustain a corporate and social order that rests on gendered hierarchies policed by sexual violence or its threat; the purpose is to reproduce the obscured social relations of the violence that sustain a gendered hierarchy that enables the overt neoliberal individualisation of the subject. 
In order to extend market values and practices "to all institutions and social action" (Brown 2003), neoliberalism produces and relies upon a disembodied and abstract model of subjectivity. This is an idea of the subject that precedes actual subjects and is the prescriptive measure and guide for their decisions and actions. Here, we have argued that the individualisation and flexibilisation of neoliberal subjectivity that is supposed to arise through competition and investment in human capital come about more concretely: through a gendered division of labour that is produced and enforced through sexual violence. In other words, neoliberalism is grafted onto bodies to sustain the political economies of male/masculine entitlement, commodification and naturalisation of female/feminine labour, sex and desire (Agathangelou, 2004).

Dollhouse's phenomenological conception of the subjectivity of lived bodies, grounded in narrative accounts of subjective experience, brings into focus the obscured conditions for subjectivity that the neoliberal notion of subjective development through atomised competition must deny and ignore. This suggests, against neoliberalism's abstract understanding of subjectivity, that conceiving subjectivity through living bodies, along with examining how political subjects emerge from the limits and openings afforded by the conditions for neoliberal subjectivity, indicates a way out of the depoliticised sphere of neoliberalism. Such a concept is precisely what Dollhouse sets out to explore. Echo's trajectory demonstrates this.

Echo is the flexible body-subject who continued to surprise and surpass expectations through her resistance, becoming the subject Rossum intended her to be. As a result, Rossum planned to extract her spinal fluid for their own purposes - an immediate example of concrete neoliberal co-optation of 
resistance and appropriation of the body and of the entrepreneurial, flexible, and resisting self (Rennebohm 2010). The necessary conditions driving this development - insertion into a gendered corporate hierarchy that catered to, policed, and relied upon sexual violence - delivered this project but in doing so, Echo gained the ability to dissent and struggle against her conditions.

Furthermore, she does so not only through a growing self-awareness but also awareness that her self is manifold and plural. In other words, as a bodily subject, Echo is always already intertwined with other bodies and with the world. If the social field that defines the conditions for abstract subjectivity is depoliticised through individualisation and responsibilisation, the social field that is Echo's body manifests itself through her ability to recall and actualise the multiple imprints that remain embodied, despite the "wiping" at the end of each engagement, and through the social relations her body produces in co-habiting the Dollhouse with her fellow Dolls and Handlers.

These intercorporeal relations are also manifold, multiple, and variegated, giving rise to disagreements and engagements that produce new possibilities at each turn. Victor embraces technology to become a cyborg warrior struggling against the chaos that Rossum's technology unleashes: a hypermasculinized body engaged in militarized dissent (Tidy 2015). Sierra "ditches the tech" to pursue an alternate pathway, though her eventual reconciliation with Victor does not restore the kind of subjective homogeneity that they experienced in their Doll states. Instead their relationship becomes a "survival-with others including others and a world that hurts us" (Choi 2015, 127). Alpha shapes his multiple subjectivities in order to care for the vulnerable, giving up his psychopathic übermensch fantasy (Vaittinen 2015). 
Neoliberalism has its own pathological fantasy: that people can be moulded into radically separated and individuated units and that this universe can be an orderly and predictable equilibrium, obviating the disruptions of politics. Dollhouse argues not only that this utopia is built on a gendered hierarchy of bodies that is policed with sexual violence but also that producing this stark neoliberal utopia unleashes forces that undermine the subjective outcomes that neoliberalism projects. Acknowledging the obscured sexual violence underpinning the neoliberal subject not only permits a more robust understanding of subjectivity as embodied in lived experience, but also disrupts the depoliticised field that neoliberal subjectivity is supposed to police.

\section{References}

Agathangelou, A. M. 2004. The Global Political Economy of Sex: Desire, Violence and Insecurity in Mediterranean Nation States. New York: Palgrave MacMillian..

Agathangelou, A. M. 2013. “Neoliberal Geopolitical Order and Value: Queerness as a Speculative Economy and Anti-Blackness as Terror." International Feminist Journal of Politics 15, 4: 453-76.

Ahmed, S. and J. Stacey, eds. 2001. Thinking Through the Skin. London: Routledge

Bacchi, C.L. and C. Beasley. 2002. "Citizen bodies: is embodiment citizenship a contradiction in terms?" Critical Social Policy 22, 2: 324-53

Balsamo, A.M. 1996. Technologies of the Gendered Body: Reading Cyborg Women. Durham, NC: Duke University Press 
Becker, G. 1993 (1964). Human capital: a theoretical and empirical analysis, with special reference to education (3rd ed.). Chicago: The University of Chicago Press.

Beier, J. M. and D. Mutimer. 2014. "Pathologizing Subjecthoods: Pop Culture, Habits of Thought, and the Unmaking of Resistance Politics at Guantanamo Bay." International Political Sociology 8, 3: 311-23.

Benjamin, W. 1978 (1934). "The Author As Producer”. In Reflections: Essays, Aphorisms, Autobiographical Writings, 220-238. New York: Schocken Books.

Berlant, L. 2011. “A Properly Political Concept of Love: Three Approaches in Ten Pages." Cultural Anthropology 26, 4: 683-91.

Bordo, S. 1993. Unbearable Weight: Feminism, Western Culture and the Body. Berkeley: University of California Press

Brown, W. 2003. "Neoliberalism and the End of Liberal Democracy". Theory and Event 7, 1 (online).

Brown, W. 2015. Undoing the Demos: Neoliberalism's Stealth Revolution. New York: Zone Books.

Bruff, I. 2014. "The Rise of Authoritarian Neoliberalism." Rethinking Marxism 26, 1: 113-29.

Butler, J. 2006. Precarious Life: The Powers of Mourning and Violence. London: Verso.

Butler, J. 2009. Frames of War: When Is Life Grievable? London: Verso.

Chandler, D. and J. Reid. 2016. The Neoliberal Subject: Resilience, Adaptation, and Vulnerability. London and New York: Rowman and Littlefield International. 
Chisholm, A. 2014. "The Silenced and Indispensible." International Feminist Journal of Politics 16, 1: 26-47.

Choi, S. 2015. "Love's Cruel Promises”. International Feminist Journal of Politics $17,1: 119-36$.

Coole, D. 2007. Merleau-Ponty and Modern Politics After Anti-Humanism. Lanham, MD: Rowman and Littlefield.

Coward, M. 2012. “Between Us in the City: Materiality, Subjectivity, and Communiity in the Era of Global Urbanization." Environment and Planning D: Society and Space 30: 468-81.

Crossley, N. 1996. “Body-subject/body-power: agency, inscription, and control in Foucault and Merleau-Ponty". Body and Society 2, 2: 99-116.

Crouch, C. 2011. The Strange Non-Death of Neoliberalism. Cambridge: Polity.

D’Aoust, A.-M. 2013. "In the Name of Love: Marriage Migration, Governmentality, and Technologies of Love." International Political Sociology 7, 3: 258-74.

Davies, M. 2005. “Do It Yourself! Punk Rock and the Disalienation of International Relations." In Resounding International Relations: On Music, Culture, and Politics, M.I Franklin (ed.), 113-40. New York: Palgrave.

Davies, W. 2014. The Limits of Neoliberalism: Authority, Sovereignty, and the Logic of Competition. Los Angeles: Sage.

Davis, A. 1983. Women, Race and Class. New York: First Vintage Books

Dean, M. 2012. “Free Economy, Strong State.” In Cahill, D., Edwards, L., and Stilwell, F. (eds), Neoliberalism Beyond the Free Market, 69-89. Cheltenham: Edward Elgar.

Dejours, C. and J.-P. Deranty. 2010. "The Centrality of Work." Critical Horizons 11, 2: $167-80$. 
Dunn, K. 2014. "Pussy Rioting: The Nine Lives of the Riot Grrrl Revolution." International Feminist Journal of Politics 16, 2: 317-34.

Elias, J. 2013. “Davos Woman to the Rescue of Global Capitalism: Postfeminist Politics and Competitiveness Promotion at the World Economic Forum." International Political Sociology 7, 2: 152-69.

Foucault, M. 2004. The Birth of Biopolitics. Basingstoke: Palgrave Macmillan.

Fraser, N. 2013. Fortunes of Feminism: From State-Managed Capitalism to Neoliberal Crisis. London: Verso Books.

Gill, R. 2008. “Culture and Subjectivity in Neoliberal and Postfeminist Times.” Subjectivity 25, 1: 432-45.

Gill, R and C. Scharff, eds. 2011. New Femininities, Post Feminism, Neoliberalism and Subjectivity. Basingstoke: Palgrave MacMillian

Griffin, P. 2015. Popular Culture, Political Economy and the Death of Feminism: Why women are in refrigerators and other stories. London and New York: Routledge.

Henderson, C.E. 2014. “AKA: Sarah Baartman the Hottentot Venus and Black Women's Identity" Women's Studies. 43: 946-59

Hozic, A. and J. True, eds. 2016. Scandalous Economies. Gender and the Politics of Financial Crisis. Oxford: Oxford University Press.

Käll, L. F. 2016. “Performativity and Expression: The Case of David Cronenberg's M. Butterfly." In Bodies, Boundaries, and Vulnerabilities: Interrogating Social, Cultural, and Political Aspects of Embodiment, L. F. Käll, (ed.), 15374. Heidelberg: Springer.

Klein, N. 2007. The Shock Doctrine: The Rise of Disaster Capitalism. New York: Henry Holt Metropolitan Books. 
Lefebvre, H. 1991. The Production of Space. Oxford and Cambridge, MA: Blackwell.

Lemke, T. 2002. "Foucault, Governmentality, and Critique.” Rethinking Marxism 14, 3: 49-64.

Leys, R. 2011. “The Turn to Affect: A Critique.” Critical Inquiry 37, 3: 434-72.

Mai, N. 2013. “Embodied Cosmopolitanisms: The Subjective Mobility of Migrants Working in the Global Sex Industry." Gender, Place, and Culture 20, 1: 10724.

McRobbie, A. 2009. The Aftermath of Feminism: Gender, Culture and Social Change. London: Sage Press

Meger, S. 2015. “Towards a Political Economy of Wartime Sexual Violence." International Feminist Journal of Politics 17, 3: 416-34.

Merleau-Ponty, M. 1968 The Visible and the Invisible, followed by Working Notes. Evanston: Northwestern University Press.

Merleau-Ponty, M. 2001. Phenomenology of Perception. London: Routledge. Mirowski, P. 2014. Never Let a Serious Crisis Go to Waste: How Neoliberalism Survived the Financial Meltdown. London and New York: Verso.

Morris, K. J. 2012. Starting with Merleau-Ponty. London and New York: Continuum.

Murphy, A. 2011. "Corporeal Vulnerability and the New Humanism." Hypatia 26, 3: 575-90.

Murphy, A. 2012. Violence and the Philosophical Imaginary. Albany: State University of New York Press.

Ong, A. 2006. Neoliberalism as Exception: Mutation in Citizenship and Sovereignty. London: Duke University Press. 
Peck, J. 2013. "Explaining (with) Neoliberalism.” Territory, Politics, Governance 1, 2: 132-57.

Prügl, E. 2015. “Neoliberalising Feminism” New Political Economy 20, 4: 614-31.

Read, J. 2009. “A Genealogy of Homo-Economicus: Neoliberalism and the Production of Subjectivity." Foucault Studies 6: 25-36.

Rennebohm, K. 2010. “The Mind Doesn't Matter, It's the Body We Want.” In Inside Joss's Dollhouse, J. Espenson, ed., 5-19. Dallas: Smart Pop.

Repo, J. 2016. “Gender Equality as Biopolitcal Governmentality in Neoliberal European Union”. Social Politics 23, 2: 307-28.

Roberts, A. 2015. “The Political Economy of Transnational Business Feminism: Problematizing the Corporate-Led Gender Equality Agenda" International Feminist Journal of Politics 17, 1: 209-31.

Rose, N. 1989. Governing the Soul: The Shaping of the Private Self. London: Routledge.

Rottenberg, C. 2014. “The Rise of Neoliberal Feminism.” Cultural Studies 28, 3 : 418-37.

Sassen, S. 2010. “A Savage Sorting of Winners and Losers: Contemporary Versions of Primitive Accumulation." Globalizations 7, 1-2: 23-50.

Scarry, E. 1985. The Body in Pain: The Making and Unmaking of the World. Oxford: Oxford University Press.

Shapiro, M. J. 2010. Time and the City: Politics, Philosophy and Genre. Abingdon and New York: Routledge.

Shepherd, L. 2008. Gender, Violence and Security: Discourse as Practice. London: Zed Books. 
Shepherd, L. 2013. Gender, Violence and Popular Culture: Telling Stories. London and New York: Routledge.

Tepe-Belfrage, D. and J. Montgomerie. 2016. "Broken Britain: Post-Crisis Austerity and the Trouble with the Troubled Families Programme". In Scandalous Economics: Gender and Politics of Financial Crises, A. Hozic and J. True (eds), 79-91. Oxford. Oxford University Press.

Thorsten, M. 2012. “Graphic 'Heart of Darkness': Two Visions of Current Affairs Comics." International Political Sociology 6, 3: 221-40.

Tidy, J. 2015. “Gender, Dissenting Subjectivity and the Contemporary Military Peace Movement in Body of War." International Feminist Journal of Politics 17, 3: 454-72.

True, J. 2012. The Political Economy of Violence Against Women. Oxford: Oxford University Press.

Vaittinen, T. 2015. “The Power of the Vulnerable Body: A New Political Understanding of Care”. International Feminist Journal of Politics 17, 1: 100-18.

Vij, R. 2013. “Affective Fields of Precarity: Gendered Antinomies in Contemporary Japan." Alternatives: Global, Local, Political 38, 2: 122-38.

Wilcox, L. 2014. "Explosive Bodies and Bounded States”. International Feminist Journal of Politics 16, 1: 66-85.

Williams, C. 2001. Contemporary French Philosophy: Modernity and the Persistence of the Subject. London and New York: The Athlone Press. Young, I.M. 2005. On Female Bodily Experience: "Throwing Like a Girl" and Other Essays. New York: Oxford University Press. 
Neoliberalism, Violence, and the Body 39 